\title{
Repair of Historic Timber Structures
}


Downloaded by [] on [25/04/23]. Copyright @ ICE Publishing, all rights reserved. 


\section{Repair of Historic Timber Structures}

\section{Second edition}

\section{David Yeomans}


Published by ICE Publishing, One Great George Street, Westminster, London SW1P 3AA.

Full details of ICE Publishing representatives and distributors can be found at: www.icebookshop.com/bookshop_contact.asp

\section{Other titles by ICE Publishing:}

Appraisal and Repair of Timber Structures, Second edition. Andrew Lawrence and Peter Ross. ISBN 978-0-7277-6178-1 Designers' Guide to Eurocode 5 - Design of Timber Buildings EN 1995-1-1 Alexander Porteous, Peter Ross and Haig Gulvanessian CBE. ISBN 978-0-7277-3162-3

Practical Design of Timber Structures to Eurocode 5

Hans Jørgen Larsen and Vahik Enjily. ISBN 978-0-7277-3609-3

www.icebookshop.com

A catalogue record for this book is available from the British Library

ISBN 978-0-7277-6438-6

(C) David Yeomans and Thomas Telford Limited 2020

ICE Publishing is a division of Thomas Telford Ltd, a wholly owned subsidiary of the Institution of Civil Engineers (ICE).

All rights, including translation, reserved. Except as permitted by the Copyright, Designs and Patents Act 1988, no part of this publication may be reproduced, stored in a retrieval system or transmitted in any form or by any means, electronic, mechanical, photocopying or otherwise, without the prior written permission of the Publisher, ICE Publishing, One Great George Street, Westminster, London SW1P 3AA.

This book is published on the understanding that the author is solely responsible for the statements made and opinions expressed in it and that its publication does not necessarily imply that such statements and/or opinions are or reflect the views or opinions of the publishers. While every effort has been made to ensure that the statements made and the opinions expressed in this publication provide a safe and accurate guide, no liability or responsibility can be accepted in this respect by the author or publishers.

While every reasonable effort has been undertaken by the author and the publisher to acknowledge copyright on material reproduced, if there has been an oversight please contact the publisher and we will endeavour to correct this upon a reprint.

Cover photo: Hotel Indigo historic timber-framed building undergoing full external restoration in Stratford-upon-Avon, Warwickshire. Nick Maslen/ Alamy Stock Photo.

Commissioning Editor: James Hobbs Production Editor: Madhubanti Bhattacharyya Marketing Specialist: April Asta Brodie

Typeset by The Manila Typesetting Company Index created by Laurence Errington Printed and bound in Great Britain by TJ International, Padstow 
01

Introduction: initial considerations

Purpose

The overall process

Conservation standards

Medical analogy

Differences from new build

Design codes

The structure of the text

Definition of terms

References

02

Structures and materials

Introduction

Pre-fire structures

Post-fire structures

Timber

Iron

Roofing materials

03

The form and behaviour of historic joints

Introduction

Mortice and tenon

Notched joints

Scarf and bridle joints $\quad 42$

The half lap 43

Joints in tension and moments on joints $\quad 43$

Ironwork 44

References $\quad 48$

$04 \ldots \ldots \ldots \ldots \ldots \ldots \ldots \ldots$ The survey $\quad 49$

Preliminary survey $\quad 50$

Detailed survey 53

Common types of distress $\quad 55$

Equipment $\quad 57$

References $\quad 59$

$05 \ldots \ldots \ldots \ldots \ldots \ldots \ldots \ldots$ Structural behaviour $\quad 61$

A cautionary tale $\quad 61$

ISCARSAH Recommendations 62

Force of habit $\quad 64$

Joint behavior $\quad 65$

Loads $\quad 65$

References $\quad 83$ 
06

The strength of timber

Early understanding $\quad 87$

Grading methods - knots $\quad 88$

Other factors 93

Moisture content 95

A practical example $\quad 97$

Conclusions 98

References $\quad 99$

07

Intervention strategy 101

The structural report 101

Historic character 102

Original structural scheme? 103

To dismantle or not? 105

Earlier repairs 106

Reliance on the carpenter 106

$\begin{array}{ll}\text { References } & 107\end{array}$

08

Decay and repair

109

Classification of repairs 109

Design codes 109

Mechanical fasteners $\quad 110$

Adhesive bonded reinforcement 118

Timber replacements 119

A patch at a mortice $\quad 119$

Refacing of a member in bending 121

New beam ends $\quad 121$

Strengthening members in bending 128

Provision of supplementary structure $\quad 129$

References 131

$09 \ldots \ldots \ldots \ldots \ldots \ldots \ldots \ldots \ldots$ Case studies 133

A purlin failure 133

St Mary-at-Hill $\quad 135$

An A-frame roof 138

Trinity College Gate $\quad 140$

References 143

Bibliography 145

Appendix - Hankinson's formula 149

$\begin{array}{ll}\text { Index } & 151\end{array}$ 


\section{Preface}

The first edition of this book was published in 2003, but there have been several developments since then, so that it has been increasingly looking rather long in the tooth. Since 2003, the International Scientific Committee on the Analysis and Restoration of Structures of Architectural Heritage (ISCARSAH) has produced its Recommendations for the analysis and restoration of historic structures, the International Standards Organization has produced an informative annex for ISO 13022 Assessment of Existing Structures to deal with heritage structures and the International Council on Monuments and Sites International Wood Committee has issued a new 'Wood Charter'. Two European working groups have also been looking at the structural assessment of historic timber structures. Having been involved with all of these initiatives, it seemed sensible that I should revise the book, to incorporate some of the ideas of these committees. But rather than simply updating the work, this has necessitated a major reworking, in part with the addition of new material, also taking a rather different approach to the subject.

Bringing a work for engineers up to date normally means taking account of recent developments in design codes. Indeed, the first edition was produced just at the time that Eurocode 5 was being published. However, there are a number of reasons why that route has not been followed here. The purpose of Eurocodes is not to improve engineering standards but rather to allow for international 'trade' within Europe, that trade to include professional services. This does not necessarily facilitate the conservation of historic buildings, particularly since those in different countries will have been built to different historic standards and traditions of workmanship. It is also the case that modern design codes do not serve conservation engineers well, as will be discussed in more than one chapter within this book. We also have to recognise that, in spite of a growing interest in conservation, research in this area remains rather limited. Moreover, to be brutally frank, many researchers have stayed at their desks and in their laboratories and have been reluctant to go out into the field to understand what engineers in practice might be doing, still less what carpenters do - or once did. It is as if they thought that, as carpentry makes your hands dirty, thinking about it might make their brains dirty (not originally my joke). 
The result is that this work can be less of a handbook to be taken down from the shelf and used like designers' manuals but more a guide to approaches to historic buildings in general and timber frames in particular. What is it then that colours my approach?

The first observation to make is that conservation involves teamwork and the engineer often needs to engage with other professionals far more than one might in new construction: architects, surveyors, conservation officers and carpenters. One might have to explain one's choices or listen to and understand the views of others that constrain those choices. One might equally be dealing directly with clients and have to explain one's recommendations to them. That means understanding something of the history of carpentry, and something of the conservation legislation. I have even had to work with lead consultants, both architects and surveyors, who knew far less about these matters than I did.

The second observation is that modern design codes and standards are written with new construction in mind. The result is that there are implicit assumptions about such things as the materials used or how joints will be made that simply do not apply to historic structures. This means that one has to navigate one's way round these codes with a degree of caution. Largely for that reason, this book does not set out to be a manual to be followed in the way that codes are often followed. There are occasions when the engineers need to think for themselves. Therefore, this book is not so much a manual as a discussion of the issues presented by a historic structure. It occasionally questions clauses in the present design codes and, for example, presents a personal view of the assessment of timber strengths. In forming these views, I have drawn on conservation projects that I have been involved in, and my work with the various committees mentioned.

There has recently been a greater international interest in the engineering aspects of conservation. There are postgraduate studies at the University of Miño and there is the International Conference on Structural Health Assessment of Timber Structures, held every two years. Although interest in the subject internationally has suggested that the book might be expended to deal with other than British structures to give it an international perspective, as far as that is possible for a book in English, space restrictions have meant that only a brief reference to the differences between British and other European traditions has been possible. 
As any other author, I have benefited from the help of others over a long period of time; too many to do justice to them all. I have learned from contractors I worked with, particularly Peter McCurdy and Hugh Harrison, from my colleague Andrew Smith with whom I worked for some years, from colleagues on the ISCARSAH committee, too many to list, and, more recently, those on the European working groups on which I have served, particularly Helena Cruz, Nicola Macchioni and Eleftheria Tsakanika. I must also acknowledge the help provided by Rob Thomas, the librarian of the Institution of Structural Engineers. 